\title{
PERANCANGAN ARSITEKTUR APLIKASI LEARNING MANAGEMENT SYSTEM DI UNIVERSITAS SLAMET RIYADI
}

\author{
Tigus Juni Betri \\ Fakultas Keguruan dan Ilmu Pendidikan, Program Studi Pendidikan Teknologi Informasi \\ Universitas Slamet Riyadi Surkarta \\ Juni.betry@gmail.com \\ Ema Utami , Hanif Al Fatta \\ Fakultas Teknik Informatika, Program Studi Magister Teknik Informatika \\ Universitas Amikom Yogyakarta \\ Ema.u@amikom.ac.id, hanif.a@amikom.ac.id
}

\begin{abstract}
ABSTRAK
E-Learning adalah salah satu solusi dalam sistem pembelajaran masa kini. Penerapan pembelajaran berbasis elektronik, proses belajar mengajar dapat menjadi lebih variatif sekaligus dapat meghilangkan kejenuhan peserta didik. Penerapan aplikasi E-Learning atau biasa disebut Learning Management System di Universitas Slamet Riyadi Surakarta selama ini tidak berjalan maksimal dikarenakan beberapa faktor. Diantaranya yang paling fundamental adalah fitur yang tersedia tidak sesuai standar penerapan E-Learning.

Solusi dari permasalahan ini adalah dengan melakukan perancangan sistem yang baru. Model pengembangan yang digunakan adalah dengan mengadopsi model Borg and Gall dengan luaran berupa prototype aplikasi. Dalam mengembangkan prototype ini, pengumpulan data kebutuhan user dilakukan terhadap stakeholder yang terkait, yaitu program studi Pendidikan Teknologi Informasi, mahasiswa dan dosen sebagai end user serta ahli di bidang IT dan kurikulum.

Hasil penelitian menunjukkan, berdasarkan kuesioner terhadap end user dapat diambil kesimpulan bahwa prototype yang ditawarkan dapat diterima di kalangan end user maupun ahli. Hal ini ditunjukkan dari angka statistik hasil analisis pengaruh antar variabel yang dirumuskan. Hipotesis pengaruh antar variabel sebagian besar atau dominan menghasilkan prototype dapat diterima.
\end{abstract}

Kata kunci: Learning Management System, Prototype, Unisri

\begin{abstract}
E-Learning is one of the solutions in current learning system. Implementation of electronicbased learning, teaching and learning process can be more varied at the same time can eliminate the saturation of learners. Implementation of E-Learning or well known as Learning Management System at Slamet Riyadi University Surakarta, so far not running maximally. Among the most fundamental features available are not in accordance with the standards of application of $E$ Learning.

The solution for this problem is better to design a new system. The development model used is to adopt the Borg and Gall model with the outline of the prototype application. In developing this prototype, data collection needs of users is done to relevant stakeholders, namely Information Technology Education courses, students and lecturers as end users as well as experts in the field of IT and curriculum.

The results showed, based on the questionnaire to end users can be concluded that the prototype offered can be accepted among the end users and experts. This is shown from the statistical results of the analysis of the influence between variables that are formulated. Hypothesis of influence between variables most or dominant produce prototype acceptable.
\end{abstract}




\section{PENDAHULUAN}

\subsection{Latar Belakang}

Universitas Slamet Riyadi (UNISRI) merupakan perguruan tinggi swasta yang didirikan oleh Yayasan Perguruan Tinggi Slamet Riyadi untuk mengenang kepahlawanan pejuang muda dari Kota Surakarta yaitu Brigjen (Anumerta) Slamet Riyadi. Jiwa kepahlawanan yang tak lekang oleh zaman itu diterjemahkan ke dalam bidang pendidikan dengan visi, misi dan tujuan. Unisri didirikan pada tanggal 21 Juni 1980 atas dasar akta pendirian Nomor 13 tahun 1980, yang selanjutnya pada tanggal 21 Juni 1980 dijadikan sebagai hari Dies Natalis. Obyek dalam penelitian ini adalah Universitas Slamet Riyadi Surakarta. UNISRI terletak di kawasan kota Solo sisi utara, tepatnya di kalurahan Kadipiro, Kecamatan Banjarsari, sebagai pintu gerbang dari arah kota Purwadadi, dan kota Sragen dari sisi timur. Dari sisi tranportasi, Unisri mudah dijangkau dari segala penjuru, dekat dari Terminal Bis Tirtonadi dan Stasiun Kereta Api Solo Balapan (berjarak sekitar $1 \mathrm{~km}$ ), serta dilalui jalur lingkar utara jurusan dari Surabaya/Sragen. serta dari Purwodadi.

Obyek dalam penelitian ini adalah Universitas Slamet Riyadi Surakarta. Termasuk di dalam obyek penelitian adalah stakholder di Universitas Slamet Riyadi di semua fakultas, yaitu diantaranya Fakultas Hukum (Ilmu Hukum); Fakultas Ekonomi (Manajemen, Akuntansi); Fakultas ISIP: (Komunikasi,Administrasi Negara,Hubungan Internasional); Fakultas KIP (PGSD, PTI, PG Paud, PPKn, BK, PBI, Bahasa Inggris); Fakultas Pertanian (Agroteknologi); Fakultas Teknologi Dan Industri Pangan (Teknologi Pangan) ; Pasca Sarjana (Magister Manajemen,Magister Ilmu Hukum, Magister Administrasi Publik ). Dalam pelaksanaan pembelajaran UNISRI memiliki sistem akademik Universitas atau website yang dapat diakses di www.unisri.ac.id . Akan tetapi dalam penerapannya belum ada aplikasi E-learning yang benar-benar terintegrasi dengan keperluan mahasiswa dan dosen sehingga dapat meningkatkan kualitas pembelajaran. Padahal di dalam kurikulum salah satu program studi yaitu Pendidikan Teknologi Informasi, dirumuskan bahwa salah satu ciri khas atau tujuan dari program studi.

\subsection{Rumusan Masalah}

Adapun yang menjadi rumusan masalah dalam penelitian "Perancangan Arsitektur Aplikasi pada Learning Management System di Universitas Slamet Riyadi Surakarta" adalah :

1. Bagaimana kegiatan dan proses pembelajaran di Universitas Slamet Riyadi dapat diimplementasikan ke dalam konsep Learning Management System ?

2. Bagaimana arsitektur aplikasi Learning Management System dapat diimplementasikan ke dalam sebuah prototype aplikasi ?

3. Bagaimana prototype aplikasi Learning Management System ini dapat di diterima sebagai rancangan yang bisa dikembangkan menjadi rekomendasi di Universitas Slamet Riyadi ?

\subsection{Batasan Penelitian}

Batasan masalah di dalam penelitian "Perancangan Arsitektur Aplikasi pada

Learning Management System di Universitas Slamet Riyadi Surakarta" adalah sebagai berikut :

1. Penelitian ini dibuat berdasarkan masukan dan saran dari hasil wawancara dengan Universitas Slamet Riyadi Surakarta mengenai Implementasi pembelajaran di Universitas Slamet Riyadi Surakarta.

2. Perizinan penelitian ini ditujukan kepada Kepala Program Studi Pendidikan Teknologi Informasi dan UPT Komputer Universitas Slamet Riyadi Surakarta.

3. Penelitian ini dilakukan dengan pengembangan sistem menggunakan model Borg \& Gall yang terdiri dari 10 langkah akan tetapi di dalam penelitian ini dimodifikasi menjadi 7 langkah.

4. Perancangan arsitektur aplikasi ini tidak membahas evaluasi kebutuhan user.

5. Perancangan arsitektur aplikasi Learning Management System menghasilkan luaran berupa perancangan arsitektur yang dirumuskan ke dalam Prototype application. 
6. Perancangan arsitektur dalam penelitian ini berfokus pada implementasi proses dan kegiatan pembelajaran ke dalam aplikasi Learning Management System

7. Perancangan dalam penelitian ini tidak termasuk membahas desain interface atau perancangan tata letak.

8. Pembangunan Prototype application dalam penelitian ini adalah aplikasi berbasis web yang diujikan secara internal dan dalam skala kecil. Pengujian berpusat pada implementasi Learning Management System

9. Validasi terdiri dari 2 macam, yakni validasi ahli untuk perancangan user dan validasi end user untuk prototype.

10. Validasi ahli dilakukan terhadap ahli TI dan ahli kurikulum dengan menggunakan pendekatan Heuristic Evaluation

11. Validasi end user dilakukan terhadap mahasiswa dan dosen dengan menggunakan HOT-fit model serta pengujiannya dihitung menggunakan metode statistik Partial Least Square (PLS)

12. Hasil akhir dari penelitian ini adalah berupa rekomendasi atau usulan sistem yang baru dengan berdasarkan rancangan yang telah melewati proses validasi

\subsection{Tujuan Penelitian}

Tujuan pada penelitian "Perancangan Arsitektur Aplikasi Learning Management System Learning Management System di Universitas Slamet Riyadi Surakarta" ini adalah

1. Mengembangkan kegiatan dan proses pembelajaran ke dalam konsep Learning Management System di Universitas Slamet Riyadi Surakarta

2. Membuat prototype aplikasi Learning Management System di Universitas Slamet Riyadi Surakarta dengan berpedoman pada hasil perancangan arsitektur aplikasi yang sudah dirancang

3. Menguji apakah prototype aplikasi Learning Management System ini dapat diterima sebagai rancangan yang bisa dikembangkan menjadi rekomendasi di Universitas Slamet Riyadi

\subsection{Manfaat Penelitian}

Manfaat dari penelitian ini terbagi menjadi 2 bagian, yaitu ;

1. Untuk Penulis

a) Menerapkan ilmu pengetahuan yang didapat di bangku kuliah ke lapangan

b) Menjadi media untuk mengimplementasikan karya ke instansi tempat penulis bekerja

2. Untuk Universitas Slamet Riyadi Surakarta

a) Sebagai masukan dan pertimbangan dalam menerapkan Learning Managament System di Universitas Slamet Riyadi Surakarta

Mempermudah proses dan kegiatan pembelajaran stakeholder di Universitas Slamet Riyadi Surakarta dengan memanfaatkan Learning Management System

\section{METODOLOGI PENELITIAN}

\subsection{Arsitektur Aplikasi}

Pengertian dari Arsitektur adalah seni dan ilmu dalam merancang bangunan. Dalam artian lebih luas, arsitektur mencakup bagaimana merancang dan membangun keseluruhan lingkungan binaan, mulai dari level makro yaitu perencanaan kota, perancangan perkotaan, arsitektur lanskap, hingga ke level mikro yaitu desain bangunan, desain perabot dan desain produk. Arsitektur juga merujuk kepada hasil-hasil proses perancangan tersebut [1]. Aplikasi merupakan penggunaan dalam suatu komputer, instruksi (instruction) atau pernyataan (statement) yang disusun sedemikian rupa sehingga komputer dapat memproses input menjadi output [2]. Istilah Arsitektur Aplikasi mengacu pada desain sebuah aplikasi, atau dimana komponen yang membentuk suatu system ditempatkan dan bagaimana mereka berkomunikasi [3]. Tujuan arsitektur aplikasi adalah untuk mendefinisikan jenis-jenis aplikasi utama dan data yang dibutuhkan untuk mengelola serta mendukung fungsi bisnis enterprise. Pada arsitektur aplikasi, harus ditentukan dan 
dituliskan secara lengkap kebutuhan yang penting untuk memproses data dan mendukung bisnis [2].

\subsection{Electronic Learning (E-Learning)}

E-Learning merupakan salah satu metode pembelajaran yang sekarang ini sedang dikembangkan dengan memanfaatkan komputer sebagai media pembelajaran, selain itu memberikan sebuah inovasi yang mempunyai kontribusi sangat besar terhadap perubahan proses belajar mengajar, proses belajar tidak lagi hanya mendengarkan uraian materi dari dosen tetapi materi bahan ajar dapat divisualisasikan dalam berbagai format dan bentuk yang lebih dinamis dan interaktif seperti file, video. musik, animasi, dan lainnya [4]. Dalam pendidikan pembelajaran $E$ Learning telah merubah cara pandang pembelajaran yaitu: dari pelatihan ke penampilan, dari ruangan ke dimana dan kapan saja, dari kertan ke "on line", dari fasilitas fisik ke fasilitas jaringan, dan dari waktu siklus ke waktu nyata [5]. Gambaran E-Learning terdiri dari management, pedagogic, interface design, technology dan ressources. Karena itu dalam pembangunan $E$ Learning dibutuhkan tim yang terdiri dari para ahli di bidang masing-masing, yaitu ; Subject Matter Expert (SME) ; Instructional Designer (ID) ; Graphic Designer (GD), dan; Ahli bidang Learning Management System (LMS).

\subsection{Jenis E-Learning}

Horton W dan Horton K ,[6] mengutarakan yang dimaksud dengan E-Learning adalah segala pemanfaatan atau penggunaan teknologi internet dan web untuk menciptakan pengalaman belajar. Ragam jenis E-Learning, dibedakan menjadi lima kategori, yaitu ; learned-led E-Learning; Instructor-led E-Learning; Facilitated E-Learning; Embedded E-Learning; Telementoring and Ecoaching.

\subsection{Arsitektur E-Learning}

Arsitektur E-Learning disebut juga Learning Technology Systems Architecture (LTSA). LTSA dipandang sebagai sistem yang relatif lengkap untuk pengembangan teknologi pembelajaran. Hal ini sejalan dengan yang dipaparkan oleh Kridanto , [7] LTSA terdiri dari lima lapis arsitektur. Setiap layer menggambarkan sebuah sistem pada level yang berbeda. Layer yang lebih tinggi memiliki prioritas yang lebih besar dan berpengaruh dalam analisis dan perancangan sistem. Dengan kata lain, layer yang lebih tinggi merupakan abstraksi dari layer yang di bawahnya, sedangkan layer yang lebih rendah merupakan implementasi dari layer yang di atasnya [8]. Kelima layer tersebut adalah Learner and Environtment Interactions, Learner Related Design Features,System Components, Implementation, Perspectives and Priorities dan Operational Components and Interoperability. Inti dari sistem pembelajaran terletak pada layer ketiga. Apabila dirangkum, komponen dalam layer 3 terdiri dari ; (1) proses, meliputi entitas siswa (learner entity), evaluasi (evaluation), pelatih (System coach), dan pengiriman (delivery). Proses dideskripsikan dengan batasan, input, proses (fungsionalitas), dan output ; (2) Penyimpanan data, yang meliputi rapor siswa (raport record) dan sumber daya pembelajaran (knowledge library). Penyimpanan data dideskripsikan dengan tipe dari informasi yang disimpan dan dengan metode search, retrieval, dan update; (3) Aliran data, yang meliputi perilaku, penilaian, informasi siswa, query, info katalog, lokator, materi pembelajaran, multimedia, konteks interaksi, dan preferensi pembelajaran. Aliran data dideskripsikan dengan konektivitas (one-way, two-way, static connections, dynamic connections, dan sebagainya) dan tipe informasi yang dialirkan.

\subsection{Learning Management System}

Learning Management System merupakan aplikasi yang mengotomasi dan mem-virtualisasi proses belajar mengajar secara elektronik [9]. Learning Management System dapat berisi materimateri yang dikemasan dalam bentuk multimedia (teks, animasi, video, sound), yang diberikan sebagai supplement dan enrichment bagi pengembangan kompetensi pembelajar. Learning Management System menawarkan sistem pembelajaran inovasi yang mencakup dalam bidang teknologi informasi, khususnya yang berbasis virtual melalui web online E-Learning, multimedia 
dan video conference. Learning Management System pembelajaran berbasis web dikembangkan secara dinamis (dinamic E-Learning) [9] . Fungsi secara umum yang harus dimiliki Learning Management System (LMS) antara lain: (1) uploading and sharing material; (2) Forum and Chatt ; (3) Quizzes and Surveys ; (4) Gathering and Reviewing Assighment; (5) Recording Grades

\subsection{Alur Penelitian}

Proses menyusun perancangan arsitektur aplikasi Learning Management System secara garis besar terdiri dari identifikasi sistem dan implementasinya ke dalam aplikasi yang berupa Prototype. Tahap identifikasi sistem secara konsep menyesuaikan dengan metode waterfall pada tahap analisa kebutuhan, desain sistem dan desain data. Analisa kebutuhan dilakukan untuk mengetahui apa saja proses bisnis yang dibutuhkan dan harus dimasukkan ke dalam sistem. Desain sistem menjelaskan tentang gambaran sistem yang dikembangkan dengan menyesuaikan identifikasi kebutuhan hasil dari analisa kebutuhan. Sementara desain data adalah rancangan database yang terdapat di dalam sistem. Langkah analisa kebutuhan terdiri dari 4 kegiatan, yaitu identify, understand, analyze dan report. Langkah tersebut adalah langkah pada tahapan pertama setelah itu proses validasi kebutuhan user. Langkah kedua yaitu desain sistem yang dilakukan dengan pendekatan tradisional. Pendekatan tradisional dilakukan karena melihat dari sisi perspektif fungsional berbeda dengan pendekatan berupa UML karena berbasis obyek [11].

Tahap implementasi Prototype dilakukan berdasarkan laporan identifikasi sistem sebagai acuan pengembangan aplikasi. Metode yang digunakan adalah dengan memetakan setiap kebutuhan sistem sesuai dengan fungsinya ke dalam aplikasi awal yang disebut prototype.

Pengumpulan data dilakukan dengan pengumpulan data primer yakni kuesioner terhadap end user pengujian prototype, wawancara Kaprodi Pendidikan Teknologi Informasi dan ahli. Selain itu metode pengumpulan juga dilakukan dengan observasi. Terakhir pengumpulan data sekunder dengan metode studi literatur. Pada pemrosesan analisis data dilakukan dengan menganalisis kebutuhan terhadap dosen dan mahasiswa untuk mengetahui apa yang menjadi sasaran mahasiswa. Selain menganalisis kebutuhan juga dilakukan analisis pengguna aplikasi. Bentuk dari bagian ini adalah berupa identifikasi masalah kebutuhan sistem solusi yang ditawarkan. Hasil tersebut diuji validitas dengan mengajukan persetujuan terhadap ahli. Ahli dalam proses validasi ini adalah ahli di bidang TI dan ahli di bidang kurikulum. Analisis data statistika digunakan untuk proses validasi data hasil kuesioner yang dibagikan kepada end user yakni metode Partial Least Square.

Alur penelitian mengadopsi pada Borg \& Gall [10] dengan modifikasi. Penelitian model Borg \% Gall yang dimodifikasi menjadi 7 langkah, yaitu ; (1) pengumpulan data ; (2) Perencanaan ; (3) pengembangan produk awal; (4) implementasi ; (5) Uji coba ; (6) Evaluasi; (7) Validasi Alur penelitian ditunjukkan gambar 1 berikut ini ; 


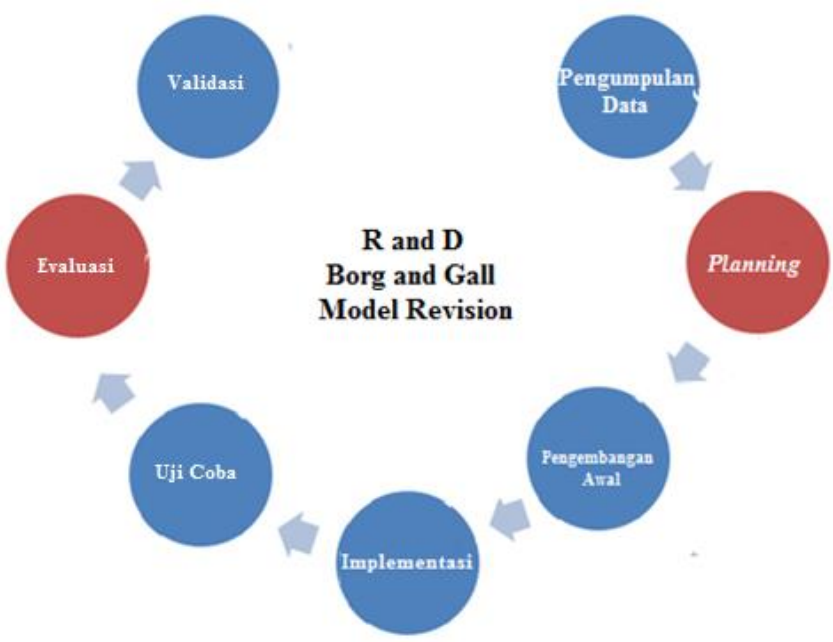

Gambar 1. Alur penelitian model Borg and Gall yang dimodifikasi.

\section{HASIL DAN PEMBAHASAN}

\subsection{Analisis Kebutuhan Sistem dan Data}

Analisis kebutuhan sistem diibaratkan sebagai perencanaan bagian komponen dengan maksud mengidentifikasikan dan mengevaluasi permasalahan, kesempatan, hambatan yang terjadi dan kebutuhan yang diharapkan sehingga dapat diusulkan menjadi suatu sistem informasi yang utuh. Analisis kebutuhan data digunakan untuk memetakan kebutuhan data. Pada proses pengumpulan data kebutuhan sistem dan data, secara garis besar dapat disimpulkan kebutuhan tersebut meliputi; (1) pendaftaran; (2)pembelajaran; (3)penilaian;(4)data mahasiswa; (5) data dosen; (6) data mata kuliah;dan (7) data penilaian.

\subsubsection{Desain Sistem}

Desain sistem disini menggunakan pendekatan terstruktur yakni dengan cara merancang kebutuhan sistem menggunakan data flow diagram atau DFD. Perancangan DFD yaitu mulai dari context diagram dan perancangan DFD. Gambar 2 berikut adalah rancangan context diagram;

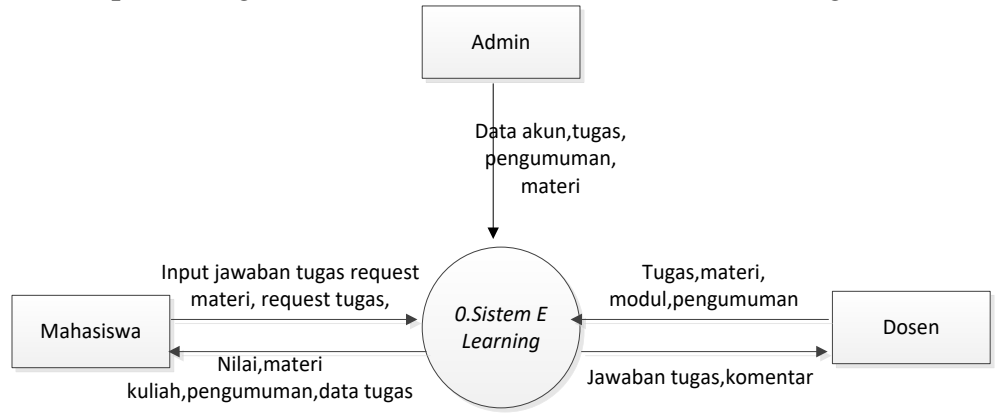

\section{Gambar 2 Context diagram sistem}

Dalam diagram ini, entitas yang terlibat adalah mahasiswa dan dosen karena mahasiswa dan dosen adalah subyek yang menggunakan sistem. Selain itu juga Administrator, akan tetapi administrator juga adalah sebagai dosen sehingga posisi entitasnya sama. Dosen berhubungan dengan sistem untuk melakukan manipulasi akun, memberikan materi , memberikan kuis/tugas ataupun memberikan penilaian. Sementara mahasiswa mernggunakan sistem untuk melakukan manipulasi profil serta melaksanakan proses pembelajaran mahasiswa itu sendiri Yaitu 
diantaranya, mengerjakan tugas/kuis, mengunduh materi dan untuk melihat nilai mata kuliah. Penjabaran dari context diagram di atas adalah DFD level 1, ditunjukkan gambar 2 berikut;

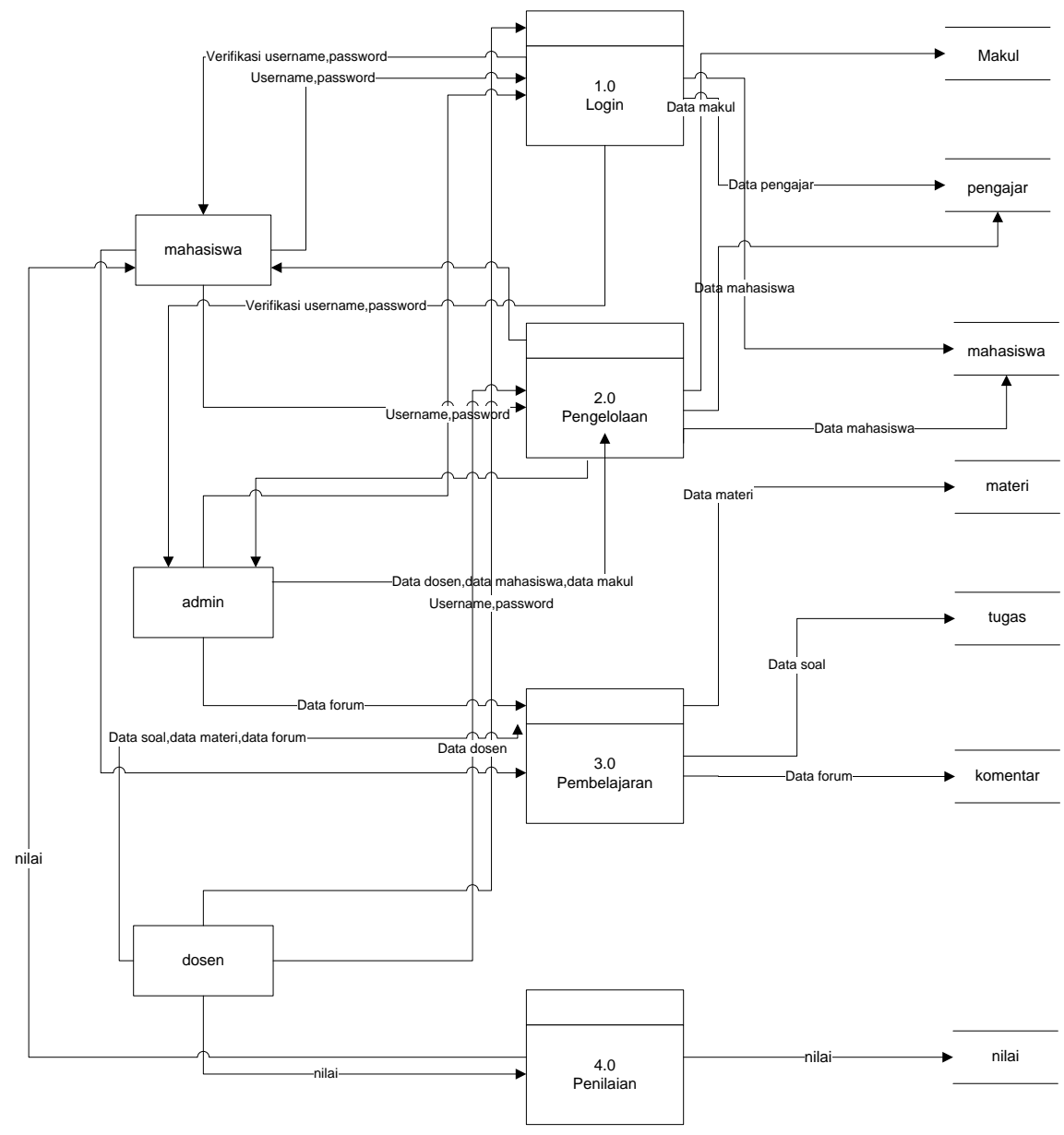

Gambar 3 Dfd level 1

Entitas dalam sistem ini adalah admin, dosen dan mahasiswa. Proses yang digambarkan dalam sistem ini adalah login, pengelolaan, pembelajaran dan penilaian.

\subsubsection{Desain Data}

Proses desain data dilakukan dengan melakukan desain ERD (entity relationship diagram) untuk menjabarkan kebutuhan database dan atribut apa saja yang dibutuhkan. Gambar 4 menunjukkan ERD perancangan ini; 


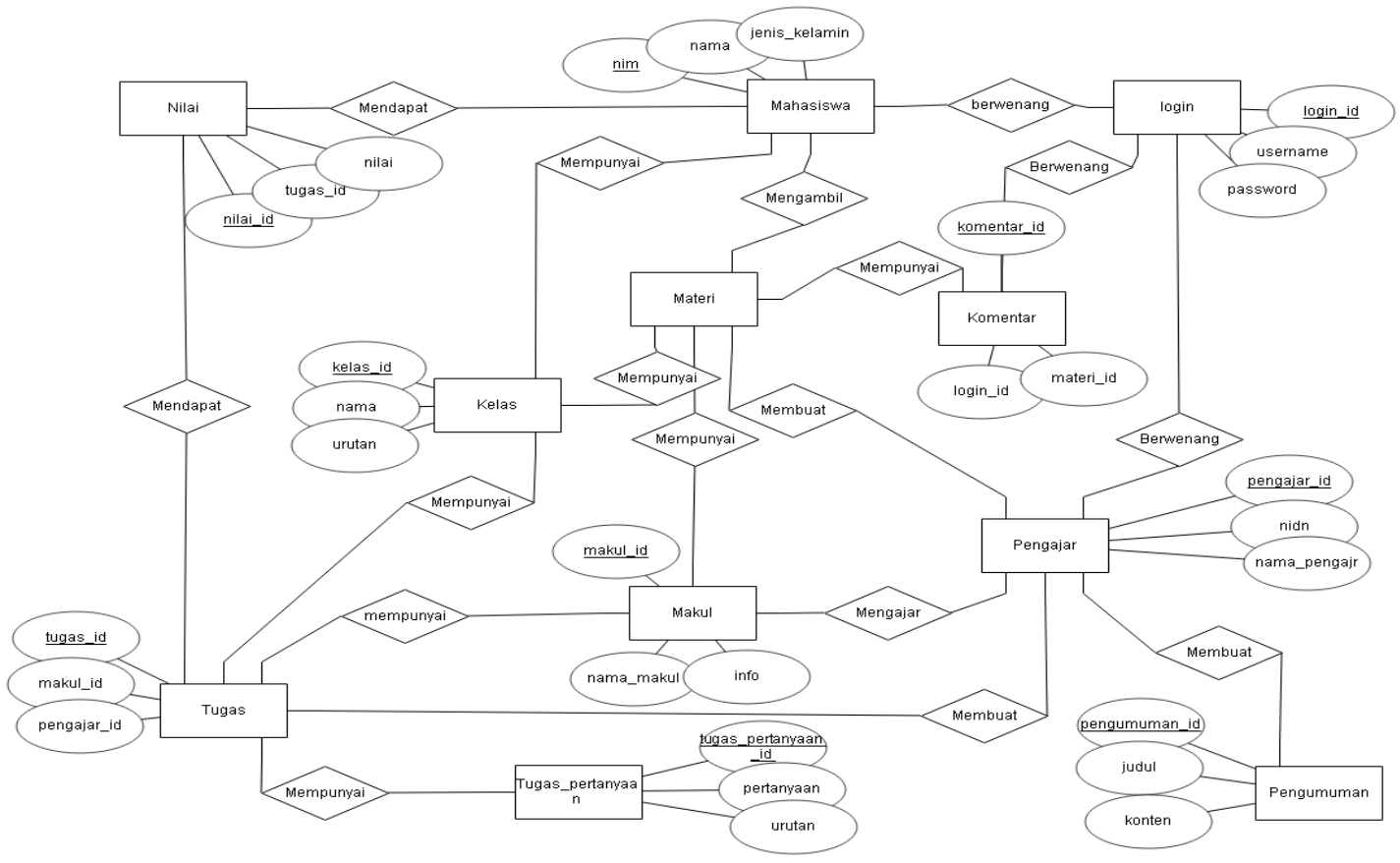

Gambar 4 Desain ERD

Padai desain ERD tersebut maka kebutuhan data di dalam sistem ini; Tabel Mahasiswa ; Tabel Pengumuman; Tabel materi; Tabel Tugas; Tabel nilai; Tabel tugas; Tabel login; Tabel login log; Tabel pengajar; Tabel kelas adalah tempat mentimpan data kelas yang ada di kampus; Tabel materi kelas; Tabel komentar; Tabel Tugas;Tabel kelas mahasiswa; Tabel makul; Tabel makul kelas; Tabel makul ajar.

\subsubsection{Desain Prototype}

Proses pembuatan prototype aplikasi e-learning dibuat berdasarkan acuan dokumen perancangan yang telah dibuat. Dengan mengacu pada 3 macam entitas yang berhubungan dengan sistem yaitu admin, dosen dan mahasiswa. Prototype dibuat dengan menggunakan PHP dan database Mysql. Berikut gambar 5 contoh tampilan prototype; 


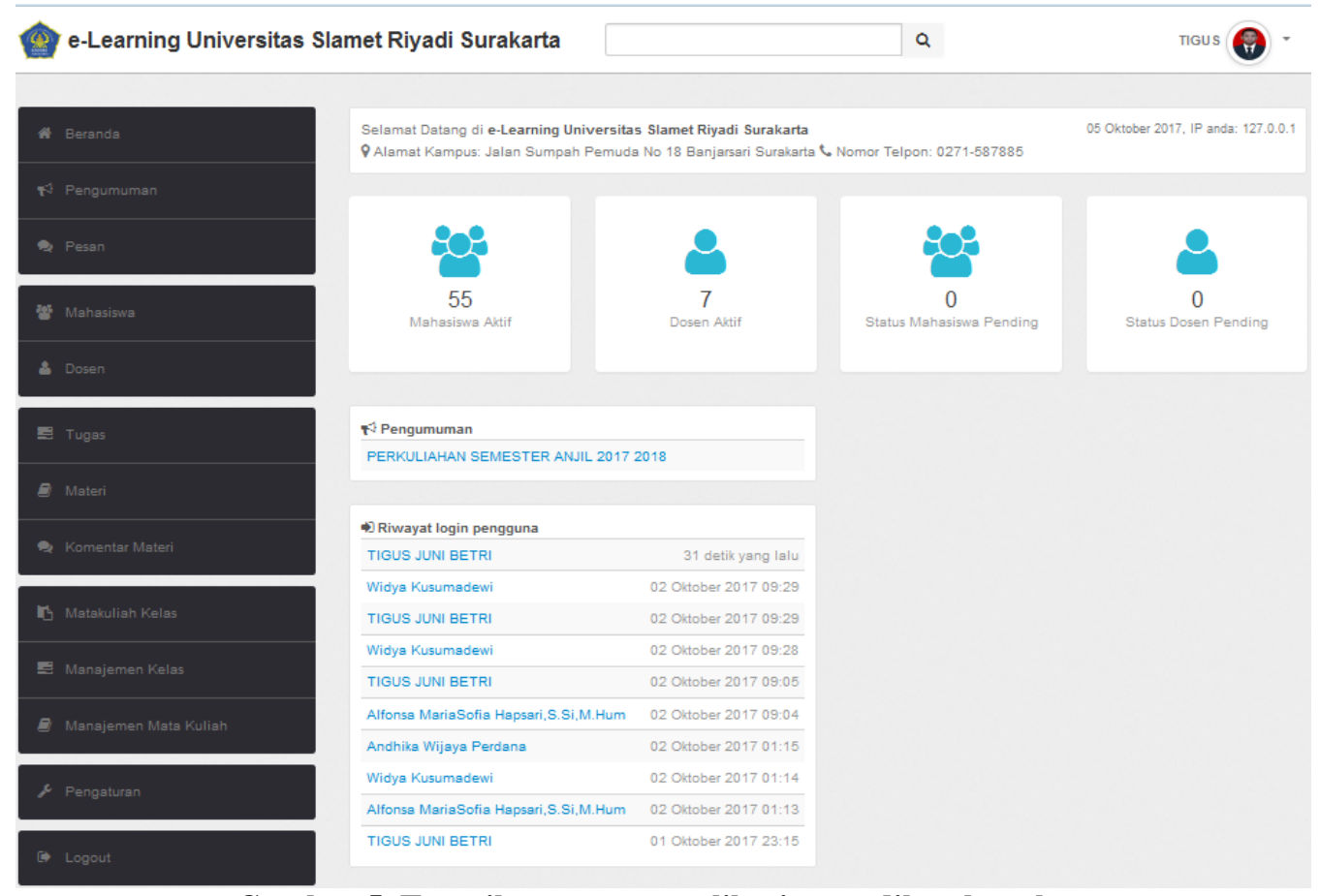

Gambar 5. Tampilan protoype aplikasi yang dikembangkan

\subsection{Evaluasi}

Evaluasi digunakan untuk mengetahui seberapa tepat suatu alat ukur mampu melakukan tugasnya sesuai dengan fungsinya. Uji validasi memiliki arti instrumen yang digunakan dapat mengukur apa yang hendak diukur. Biasanya digunakan dengan menghitung korelasi antara skor butir instrumen dengan skor total [12]. Penelitian ini menggunakan model evaluasi HOT-fit (Human, Organization, Technology). Model ini melibatkan 3 faktor utama yakni Pengguna, Organisasi, dan Teknologi. Penelitian ini menunjukkan bahwa hubungan antara variabel Human, Organization, dan Technology mempunyai hubungan yang cukup kuat dan positif yang saling mempengaruhi satu dengan yang lain serta ketiganya mempunyai hubungan yang kuat dan searah terhadap Net Benefit dari sistem. Model ini dikemukakan oleh Yusof M.M., Paul RJ dan Stregioulas, L. K [13]. Dasar pemikiran model ini berasal dari model evaluasi sistem informasi DeLone McLean [14].

Tiga faktor ini berhubungan dengan 7 dimensi komponen turunannya, yaitu System Quality (Kualitas Sistem), Information Quality ( Kualitas Informasi), Service Quality (Kualitas Layanan), System Use (Penggunaan Sistem), User Satisfaction ( Kepuasan Pengguna), Organization Structure (Struktur organisasi) dan Net Benefit. Faktor-faktor dari model evaluasi ini kemudian dirumuskan menjadi hipotesis analisis pengaruh yang kemudian nanti dihitung dengan model Partial Least Square menggunakan software SMART PLS. Untuk mencari hipotesis pengaruh antar variabel, terlebih dahulu dirumuskan faktor-faktor apa saja yang berhubungan. Dimensi-dimensi ini mempengaruhi satu dengan yang lain. Pada Partial Least Square, faktor-faktor atau variabel turunan tersebut disebut dengan variabel eksogen dan variabel endogen. Variabel eksogen adalah variabel yang tidak diprediksi oleh variabel-variabel yang lain yang terdapat dalam model. Konstruk eksogen tersebut merupakan konstruk yang dituju oleh garis dengan satu ujung anak panah Sedangkan variabel endogen adalah variabel yang merupakan faktor-faktor yang diprediksi oleh satu atau beberapa konstruk. Berdasarkan hal tersebut, maka dapat diambil kesimpulan;

1. Variabel eksogen : kualitas sistem,kualitas informasi, kualitas layanan, struktur organisasi 
2. Variabel endogen : penggunaan sistem, kepuasan pengguna, Net Benefit. Hubungan tersebut dirumuskan ke dalam HOT-fit model, menjadi gambar 6 berikut;

TECHNOLOGY HUMAN

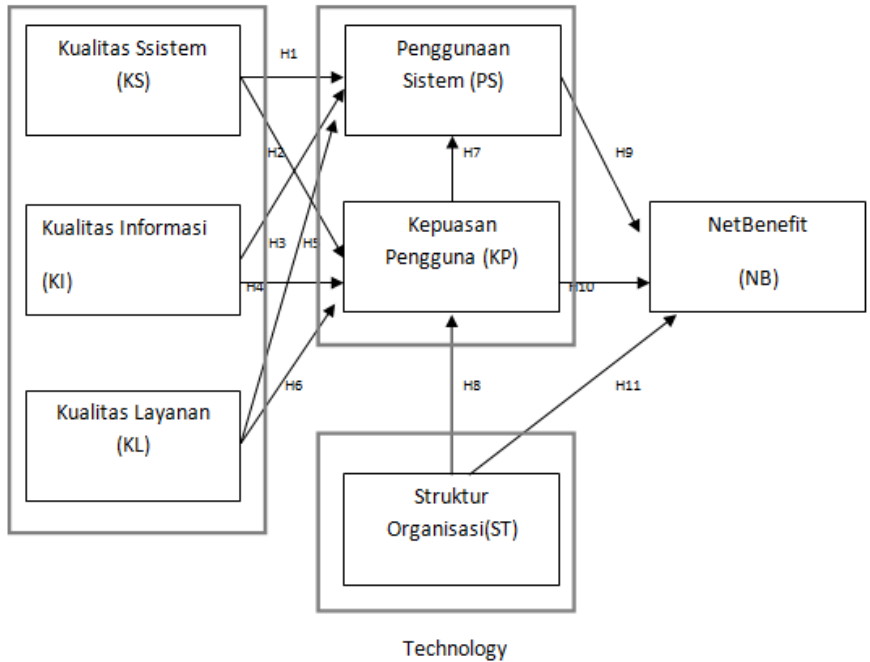

Gambar 6 Perumusan Hipotesa dengan HOT-fit model

Perumusan hipotesis tersebut dijabarkan ke dalam tabel hipotesis pada tabel 1 berikut;

Tabel 1 Hipotesis Pengaruh

\begin{tabular}{|l|l|l|l|}
\hline \multicolumn{2}{|c|}{ Hipotesis Pengaruh } \\
\hline \multicolumn{1}{|c|}{ No } & \multicolumn{1}{|c|}{ Dari } & \multicolumn{1}{c|}{ Terhadap } \\
\hline 1 & H1 & KS & PS \\
\hline 2 & H2 & KS & KP \\
\hline 3 & H3 & KI & PS \\
\hline 4 & H4 & KI & KP \\
\hline 5 & H5 & KL & PS \\
\hline 6 & H6 & KL & KP \\
\hline 7 & H7 & KP & PS \\
\hline 8 & H8 & ST & KP \\
\hline 9 & H9 & PS & NB \\
\hline 10 & H10 & KP & NB \\
\hline 11 & H1 & ST & NB \\
\hline
\end{tabular}

\subsubsection{Perumusan Variabel}

Data primer diperoleh dari kuesioner yang diujikan terhadap responden yaitu sebanyak 60 mahasiswa. Kuesioner berisi pernilaian terhadap prototype. Pilihan jawaban dipetakan dalam bentuk Likert scale dengan rentang nilai 1 (STS/sangat tidak setuju) ; 2 ( TS/tidak setuju) ; 3 ( N / Netral), 4 (S / Setuju) dan 5 ( S/ Sangat setuju). Tujuan nya adalah mengevaluasi prototype. Penyusunan kerangka kerja evaluasi dimulai dengan menginterpretasikan setiap aspek pada model HOT-fit menjadi satu pernyataan yang terukur, yang terdiri dari variabel dan indikator-indikator seperti tabel 2 berikut;

Tabel 2 Variabel Dan Indikator Model HOT-fit dalam Kuesioner

\begin{tabular}{|l|}
\hline \multicolumn{1}{|c|}{ Indikator } \\
\hline 1.
\end{tabular}


2. $\mathrm{KS} 2=$ prototype mudah untuk dipelajari

3. $\mathrm{KS} 3=$ Prototype bermanfaat dalam proses pembelajaran

4. $\mathrm{KS} 4=$ Prototype dapat terintegrasi

5. $\mathrm{KS} 5=$ Prototype memiliki fasilitas petunjuk penggunaan

6. $\mathrm{KS6}=$ Prototype mencakup banyak fitur dan lengkap

7. $\mathrm{KS} 7=$ Protoype memiliki hak akses

1. $\mathrm{KI} 1=$ Prototype menghasilkan informasi yang lengkap

2. $\mathrm{KI} 2=$ Prototype menghasilkan informasi yang benar

3. $\mathrm{KI} 3=$ Prototype menghasilkan informasi mudah dipahami

4. $\mathrm{KI} 4=$ Prototype menghasilkan informasi yang tepat waktu

5. $\mathrm{KI} 5=$ Informasi Prototype dapat dipertanggungjawabkan

6. KI6 = Prototype menghasilkan informasi yang relevan

7. $\mathrm{KI} 7=$ Prototype menghasilkan informasi sama dengan input

1. KL1 = layanan dari penyedia sistem cepat jika dibutuhkan bantuan

2. $\mathrm{KL} 2$ = penyedia memberikan jaminan layanan terhadap pengguna

3. KL3 = penyedia memiliki sikap peduli ketika membantu user

4. $\mathrm{KL} 4=$ penyedia menyelesaikan masalah

1. PS1 = pengguna selalu dapat menggunakan sistem

2. $\mathrm{PS} 2$ = pengguna dapat bergantung pada sistem

3. $\mathrm{PS} 3=$ pengguna percaya prorotype dapat mempermudah pekerjaan

4. $\mathrm{PS} 4=$ pengguna dapat menerima prototype sistem dengan baik

5. PS5 = pengguna punya keterampilan baik untuk menggunakannya

6. PS6 $=$ pengguna dapat mengikuti pelatihanpelatihan

yang diadakan untuk menggunakan prototype sistem

1. $\mathrm{KP} 1=$ Prototype membantu dalam mengolah informasi

2. $\mathrm{KP} 2=$ Prototype sistem memuaskan

1. $\mathrm{ST} 1=$ organisasi dapat mempertimbangkan latar

belakang pendidikan calon pengelola sistem

2. $\mathrm{ST} 2=$ organisasi memberikan pelatihan yang dianggap perlu bagi pengelola sistem

3. $\mathrm{ST} 3=$ organisasi memiliki komunikasi yang baik dengan para pengelola sistem

4. ST4 = organisasi mampu mengatasi konflik antar pengelola sistem

5. ST5 = organisasi memberikan kompensasi sesuai dengan peraturan pemerintah

6. ST6=Prototype sistem dapat menyesuaikan pengguna sebagai pengelola

1. NB1 = prototype mempermudah proses yang berhubungan dengan pembelajaran

2. $\mathrm{NB} 2=$ Prototype membantu menjadi lebih efektif dan efisien

3. $\mathrm{NB} 3=$ Prototype dapat menurunkan tingkat kesalahan

4. $\mathrm{NB} 4=$ Prototype meningkatkan komunikasi antar divisi

5. $\quad$ NB5 $=$ Prototype menjadikan kinerja universitas dan organisasi menjadi lebih baik

6. NB6 $=$ Prototype dapat meningkatkan komunikasi antara mahasiswa dan dosen

7. $\mathrm{NB} 7=$ Prototype dapat meningkatkan kinerja mahassiwa dan universitas dalam menghadapi persaingan yang ada saat ini

8. $\quad$ NB8 $=$ Prototype dapat mendukung visi dan misi dari organisasi

\subsubsection{Pengolahan Data Variabel}

Responden terbagi menjadi 2 yaitu responden dosen dan mahasiswa (end user sebanyak 60 orang). Variabel responden dosen dan mahasiswa diolah menggunakan software SMART PLS, berdasarkan kuesioner yang telah disebar hasilnya pada tabel 3 berikut :

Tabel 3 Tabel hasil kuesioner 


\begin{tabular}{|c|c|c|c|c|c|c|}
\hline & STS (1) & TS (2) & $\mathbf{N}(3)$ & S (4) & SS (50) & Total \\
\hline KS1 & 0 & 2 & 19 & 35 & 4 & 60 \\
\hline $\mathrm{KS} 2$ & 0 & 4 & 22 & 30 & 4 & 60 \\
\hline KS3 & 0 & 2 & 19 & 34 & 5 & 60 \\
\hline KS4 & 0 & 2 & 18 & 35 & 5 & 60 \\
\hline KS5 & 0 & 2 & 9 & 43 & 7 & 60 \\
\hline KS6 & 1 & 1 & 9 & 42 & 7 & 60 \\
\hline KS7 & 0 & 3 & 29 & 24 & 4 & 60 \\
\hline KI1 & 0 & 2 & 10 & 42 & 6 & 60 \\
\hline KI2 & 0 & 2 & 9 & 46 & 3 & 60 \\
\hline KI3 & 0 & 3 & 17 & 36 & 4 & 60 \\
\hline KI4 & 0 & 2 & 15 & 9 & 11 & 60 \\
\hline KI5 & 0 & 3 & 9 & 44 & 4 & 60 \\
\hline KI6 & 0 & 3 & 11 & 42 & 5 & 60 \\
\hline KI7 & 1 & 2 & 6 & 44 & 7 & 60 \\
\hline KL1 & 0 & 2 & 11 & 42 & 5 & 60 \\
\hline KL2 & 1 & 2 & 18 & 39 & 0 & 60 \\
\hline KL3 & 0 & 3 & 20 & 34 & 3 & 60 \\
\hline KL4 & 0 & 3 & 19 & 35 & 3 & 60 \\
\hline KP1 & 0 & 4 & 15 & 40 & 1 & 60 \\
\hline KP2 & 0 & 3 & 18 & 37 & 2 & 60 \\
\hline ST1 & 0 & 1 & 14 & 44 & 1 & 60 \\
\hline ST2 & 0 & 1 & 16 & 43 & 0 & 60 \\
\hline ST3 & 0 & 0 & 18 & 38 & 4 & 60 \\
\hline ST4 & 0 & 1 & 19 & 39 & 1 & 60 \\
\hline ST5 & 0 & 2 & 15 & 42 & 1 & 60 \\
\hline ST6 & 0 & 0 & 17 & 42 & 1 & 60 \\
\hline PS1 & 1 & 4 & 15 & 38 & 3 & 60 \\
\hline PS2 & 0 & 6 & 17 & 36 & 1 & 60 \\
\hline PS3 & 0 & 4 & 16 & 30 & 10 & 60 \\
\hline PS4 & 0 & 4 & 17 & 35 & 4 & 60 \\
\hline PS5 & 0 & 4 & 14 & 38 & 4 & 60 \\
\hline PS6 & 0 & 0 & 17 & 38 & 5 & 60 \\
\hline NB1 & 0 & 6 & 19 & 30 & 5 & 60 \\
\hline NB2 & 0 & 10 & 12 & 34 & 4 & 60 \\
\hline NB3 & 0 & 3 & 17 & 35 & 5 & 60 \\
\hline NB4 & 0 & 1 & 15 & 39 & 5 & 60 \\
\hline NB5 & 0 & 4 & 15 & 35 & 6 & 60 \\
\hline NB6 & 0 & 1 & 14 & 41 & 4 & 60 \\
\hline NB7 & 0 & 6 & 21 & 29 & 4 & 60 \\
\hline NB8 & 0 & 3 & 14 & 38 & 5 & 60 \\
\hline
\end{tabular}

\subsection{Uji Validitas}

Tabulasi data ada 2, yaitu responden dosen dan mahasiswa. Data responden dosen dan mahasiswa dianalisis menggunakan SMARTPLS. Langkah menyelesaikan model persamaan dengan pendekatan jalur ini adalah dengan menghitung outer model dan inner model yang terdiri dari Validitas Konvergen; Validitas Diskriminan, Rerata (ave); Composite Reliability, Croncbach Alpha; serta path coefficient dan t-value.

\subsubsection{Validitas Konvergen}


Validitas Konvergen mensyaratkan bahwa alat ukur secara tepat mengukur konstruk yang dimaksud. Convergent validity sama dengan outer loading/loading factor yang nilainya dikatakan tinggi apabila lebih dari 0,7.Berikut gambar 7, simulasi dengan software SMARTPLS;

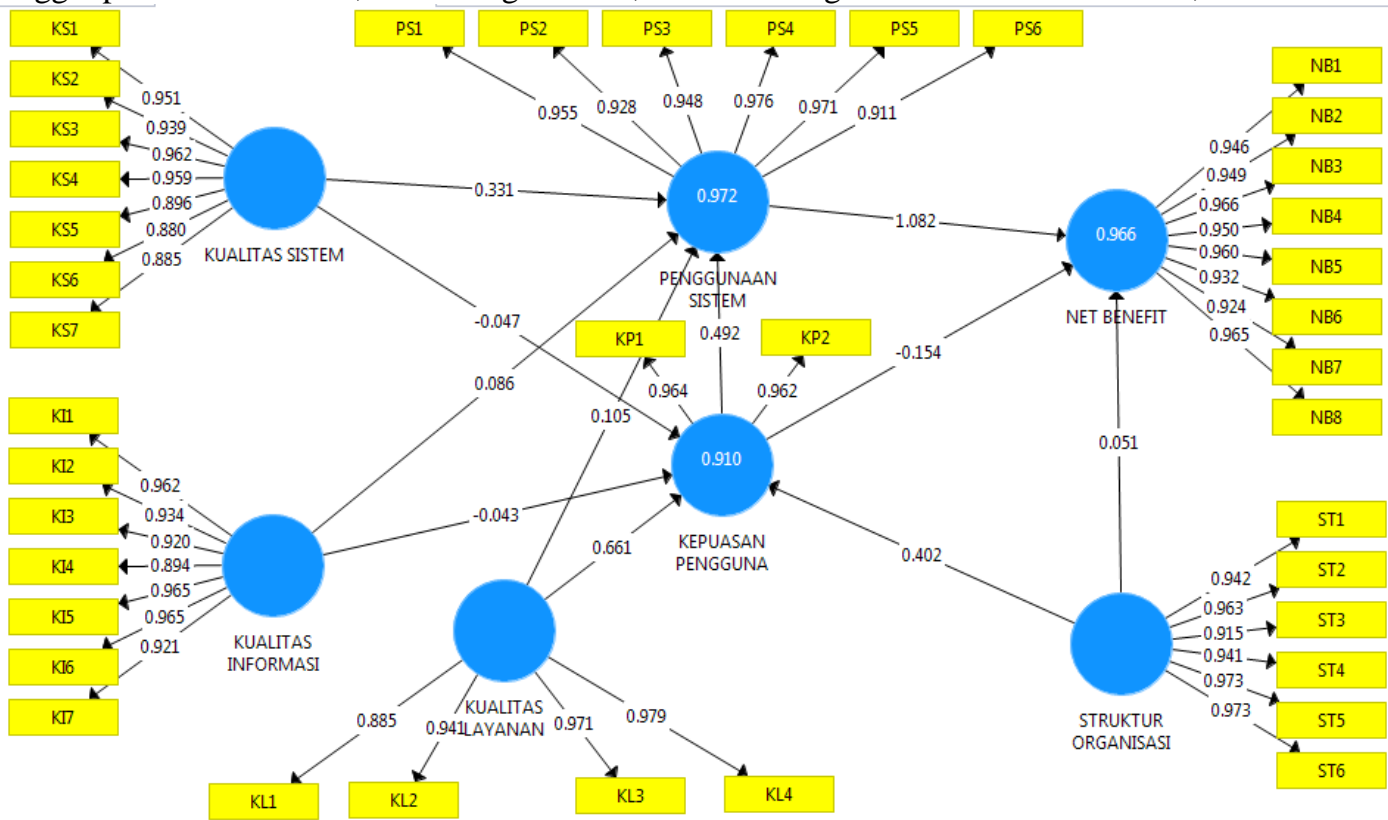

Gambar 7 Hasil Loading Factor indikator

Hasil perhitungan tersebut menunjukkan bahwa nilai loading factor di atas 0.70 , sehingga semua indikator telah memenuhi convergent validity dan dinyatakan cukup.

\subsubsection{Validitas Diskriminan}

Validitas diskriminan digunakan untuk menguji alat ukur, apakah secara tepat mengukur konstruk yang diukur, bukan konstruk yang lain. Tabel 4 berikut menunjukkan nilai average;

Tabel 4 Nilai AVE

\begin{tabular}{|l|l|l|}
\hline No & Indikator & Nilai AVE \\
\hline 1 & KS & 0.856 \\
\hline 2 & KI & 0.879 \\
\hline 3 & KL & 0.892 \\
\hline 4 & KP & 0.927 \\
\hline 5 & PS & 0.899 \\
\hline 6 & ST & 0.905 \\
\hline 7 & NB & 0.901 \\
\hline
\end{tabular}

Setelah dianalisis pada nilai, hasil kuesioner yang didapat menunjukkan kecenderungan bahwa semakin sedikit responden yang memilih angka rendah ( tidak setuju atau tidak setuju ) akan menghasilkan nilai rerata yang semakin tinggi, hal ini dapat terlihat dengan nilai rerata yang dihasilkan variabel ST dan KP yang tinggi.

\subsubsection{Realibilitas Konstruk}

Uji reliabilitas diukur dengan dua kriteria yaitu composite reliability dan cronbach alpha dari blok indikator yang mengukur konstruk. Hasil dari pengolahan dengan menggunakan Smart PLS dapat dilihat pada Tabel 5 berikut; 
Tabel 5 Tabel hasil reliabilitas konstruk

\begin{tabular}{|c|c|c|c|}
\hline No & Indikator & Composite Realibility & Cronbachs Alpha \\
\hline 1 & KS & 0.977 & 0.972 \\
\hline 2 & KI & 0.981 & 0.977 \\
\hline 3 & KL & 0.971 & 0.959 \\
\hline 4 & KP & 0.962 & 0.921 \\
\hline 5 & PS & 0.982 & 0.977 \\
\hline 6 & ST & 0.983 & 0.979 \\
\hline 7 & NB & 0.986 & 0.984 \\
\hline
\end{tabular}

Pada Tabel 5 diketahui bahwa composite reliability dan cronbachs alpha pada model menunjukkan konstruk telah memenuhi reliabilitas. Konstruk dinyatakan reliabel jika nilai composite reliability lebih besar 0,7. sedangkan Cronbach Alpha lebih besar dari 0,6

\subsubsection{Model Struktural}

Inner model digunakan untuk mengevaluasi hubungan antar konstruk laten seperti yang telah dihipotesiskan dalam penelitian ini. Pengaruh antar variabel ditunjukkan koefisien parameter dan signifikansi t-statistiknya. Berikut hasil hipotesis tabel 6 ;

Tabel 6 Hasil hipotesis

\begin{tabular}{|c|c|c|c|c|c|}
\hline \multirow{2}{*}{$\mathbf{H}(\mathbf{n})$} & \multicolumn{2}{|c|}{ Jalur } & \multirow{2}{*}{$\begin{array}{c}\text { Path } \\
\text { coefficient } \\
(\beta)\end{array}$} & \multirow{2}{*}{$T$ value(t) } & \multirow{2}{*}{$\begin{array}{c}\text { Hasil } \\
\text { pengujian } \\
\alpha=0,05\end{array}$} \\
\hline & Dari & $\mathbf{K e}$ & & & \\
\hline H1 & $\mathrm{KS}$ & PS & 0,33 & 2,63 & Diterima \\
\hline $\mathrm{H} 2$ & $\mathrm{KS}$ & KP & 0,40 & 3,16 & Diterima \\
\hline H3 & $\mathrm{KI}$ & PS & 0,09 & 0,92 & Ditolak \\
\hline $\mathrm{H} 4$ & $\mathrm{KI}$ & KP & $-0,04$ & 0,26 & Ditolak \\
\hline H5 & KL & PS & 0,11 & 2,55 & Diterima \\
\hline H6 & KL & KP & 0,67 & 3,34 & Diterima \\
\hline $\mathrm{H7}$ & KP & PS & 0,50 & 3,94 & Diterima \\
\hline $\mathrm{H} 8$ & ST & KP & $-0,05$ & 0,22 & Ditolak \\
\hline H9 & PS & NB & 1,09 & 4,94 & Diterima \\
\hline $\mathrm{H} 10$ & $\mathrm{KP}$ & NB & $-0,15$ & 0,84 & Ditolak \\
\hline H11 & ST & NB & 0,05 & 2,49 & Diterima \\
\hline
\end{tabular}

Dari Tabel 6 diatas dapat diketahui hipotesis ditolak maupun yang diterima dengan melihat nilai dari $\mathrm{T}$ statistik dan koefisien jalurnya. Dalam pengujian hipotesis tingkat signifikansi yang digunakan adalah $95 \%(\alpha=0.05)$. Nilai $t$ tabel dengan tingkat signifikasi $95 \%$ adalah 1,96 .

\subsection{Pembahasan}

Berdasarkan evaluasi, maka ; (1) Analisis pengaruh memperlihatkan hipotesa terhadap analisis pengaruh antar variabel. Penerimaan prototype aplikasi ini dipengaruhi oleh faktor kualitas sistem, kualitas informasi, kualitas layanan, penggunaan sistem, kepuasan sistem serta peran struktur organisasi.; (2) Kualitas sistem berpengaruh terhadap penggunaan sistem dan kepuasan pengguna. Hal ini berarti semakin tinggi kualitas sistem pada prototype aplikasi ini, maka semakin meningkat penggunaan sistem dan kepuasan pengguna terhadap prototype;(3) Kualitas informasi tidak berpengaruh terhadap penggunaan sistem dan kepuasan pengguna; (4) Kualitas layanan berpengaruh terhadap penggunaan sistem dan kepuasan pengguna. Hal ini berarti semakin tinggi kualitas layanan pada prototype, maka semakin meningkat pula penggunaan sistem dan kepuasan 
pengguna terhadap prototype; (5) Kepuasan pengguna berpengaruh terhadap penggunaan sistem. Hal ini berarti semakin meningkat kepuasan pengguna maka semakin tinggi penggunaan sistem ; (6) Struktur organisasi tidak berpengaruh terhaap kepuasan pengguna.; (7) Penggunaan sistem berpengaruh terhadap Net Benefit. Hal ini berarti semakin tinggi angka penggunaan sistem maka semakin tinggi Net Benefit yang didapat dari prorotype; (8) Kepuasan pengguna tidak berpengaruh terhadap Net Benefit ; (9) Struktur organisasi berpengaruh terhadap Net Benefit, berarti semakin meningkat peranan struktur organisasi maka semakin tinggi Net Benefit yang didapatkan dari prototype.

\section{KESIMPULAN}

Kesimpulan penelitian yang membahas tentang perancangan arsitektur aplikasi Learning Management System ini menjawab rumusan masalah yaitu, Kegiatan dan proses pembelajaran di Universitas Slamet Riyadi dapat diimplementasikan ke dalam konsep Learning Management System. Arsitektur aplikasi Learning Management System di universitas Slamet Riyadi tersebut dapat diimplementasikan dengan baik ke dalam prototype dengan menggunakan metode pengembangan Borg and Gall yang dimodifikasi.

Selain itu prototype diujikan sehingga mendapatkan hasil validasi pada pengujian terhadap responden yakni end user, serta narasumber yakni ahli di bidang TI dan bidang kurikulum. Pengujian dilakukan dengan berdasarkan HOT-fit model, yang mencakup Human, Organization dan Technology. Dengan pemetaan HOT-fit model tersebut, berhasil dijabarkan beberapa hipotesis penerimaan dimana angka yang dihasilkan menunjukkan bahwa prototype dapat diterima dengan baik oleh end user dalam hal ini adalah dosen dan mahasiswa. Sedangkan pengujian terhadap narasumber ahli TI dan kurikulum dilakukan dengan heuristic evaluation dengan menghasilkan pendapat serta perbaikan dari ahli bahwa prototype dapat diterima dengan baik sehingga dapat menjadi pertimbangan rekomendasi untuk dikembangkan

\section{DAFTAR PUSTAKA}

[1] Robertson \& Sribar, 2001, The Adaptive Enterprise IT Infrastruktur Strategies to Manage Change and Enable Growth, London: Intel Press

[2] Jogiyanto, 2008, Analisis dan Desain Sistem Informasi : Pendekatan Terstruktur Teori dan Praktek Aplikasi Bisnis, Yogyakarta : Andi

[3] Wahono, R.S., 2008, Definisi dan Komponen E-Learning. Jakarta : Gramedia

[4] Wahono, S.R., 2007, Sistem E-Learning Berbasis Model Motivasi Komunitas, Jurnal Teknodik No. 21/XI/TEKNODIK/ AGUSTUS/2007, Agustus 2007

[5] Magai,A., 2009, E-Learning in The Indonesia Education Syste. Asia Pacific Cyber Education Journal Vol 1 No 2. 2005 hlm 15-24.

[6] Horton,W., and Horton, K., 2003, E-Learning Tools and Technologies: A Cosrumer's guide for trainers, teachers, educators and instructional desiners. London

[7] Kridanto, S., 2005, Pengembangan Learning Content Management System yang Mendukung Peningkatan Efektivitas Proses Belajar Jarak Jauh, Jurusan Teknik elektro,Fakultas Teknologi Industri, Universitas Kristen Petra. Agustus 2005

[8] Farance, F., 1998, Learning Technology System Architecture (LTSA). Division Farance Inc. 
[9] Iyan Supriyana, 2008, Perencanaan Arsitektur Perusahaan dengan Menggunakan The Open Group Architecture Framework (TOGAF) Studi Kasus Bakosurtanal, Tesis, MTI-UI

[10] Borg, W. R. and Gall, M. D, (1989) Educational Research: An Introduction 5th. edn. New York: Longman

[11] Satzinger, J., Jackson, R \& Burd, S., 2012, System Analysis and Design in a Changing World, USA, Boston : Course Technology

[12] Sugiyono. 2004. Statistik Untuk Penelitian . Jakarta: Alfabeta

[13] Yusof, R. J. Paul and L. K. Stergioulas, 2006, "Towards a Framework for Health Information Systems Evaluation," Proceedings of the 39th Hawaii International Conference on System Sciences.

[14] DeLone, W, H., dan Mclean, E.R. 2003. The DeLone and McLean Model of Information System Success: A Ten-Year Update Management Information System, Vol 3, Nomor 1. Institue Of Management 